\title{
Alcobaça ALLELE AND GENOTYPIC BACKGROUNDS AFFECT YIELD AND FRUIT SHELF LIFE OF TOMATO HYBRIDS
} \author{
Azevedo ${ }^{4}$ \\ ${ }^{I}$ UFLA - Depto. de Agricultura, C.P. 37 - 37200-000 - Lavras, MG - Brasil. \\ ${ }_{3}^{2}$ Depto. de Biologia - UFLA. \\ Agroflora-Sakata, C.P.427 - 12906-840 - Bragança Paulista, SP - Brasil. \\ ${ }^{4}$ Rhae/CNPq scholarship. \\ *Corresponding author <wrmaluf@ufla.br>
}

Túlio José Mendes Dias ${ }^{1}$; Wilson Roberto Maluf ${ }^{*}$; Marcos Ventura Faria ${ }^{2}$; Joelson André de Freitas $^{3}$; Luiz Antonio Augusto Gomes ${ }^{4}$; Juliano Tadeu Vilela Resende'; Sebastião Márcio de

\begin{abstract}
Post-harvest shelf life of tomato fruit may be increased by deploying mutant alleles which affect the natural ripening process and/or by a favorable genotypic background. Among the several ripening mutant genes, alcobaça (alc) has proved to be highly efficient in increasing shelf life of commercial tomato fruits, especially in heterozygosis, a state at which no limiting deleterious effects upon fruit color occur. The effects of heterozygosity in the alcobaça locus $\left(\right.$ alc $\left.{ }^{+} / a l c\right)$ on yield and fruit quality traits of tomato hybrids with three genotypic backgrounds. We evaluated three pairs of hybrids obtained from crosses between the near-isogenic pollen source lines Flora-Dade $\left(\right.$ alc $^{+} /$alc $\left.^{+}\right)$and TOM-559 (alc/alc), and three maternal lines (Stevens, NC-8276 and Piedmont). The six treatments were factorial combinations of two different status in the alc locus (alc $c^{+} /$alc and $\left.a l c^{+} / a l c^{+}\right)$versus three different genotypic backgrounds (maternal lines). Fruits were harvested at the breaker stage of maturation and stored in shelves at $21^{\circ} \mathrm{C}$ for 14 days. Yield and fruit quality traits were then evaluated. Regardless of the background, the alc allele in heterozygosis $\left(\right.$ alc ${ }^{+} /$alc $)$did not interfere with the total yield, commercial yield, average mass per fruit, average mass per commercial fruit, fruit shape, or with fruit peduncular scar diameter. The alc $/$ alc genotype reduced the rate of firmness loss and delayed evolution of the red color of the fruit, thus contributing to an increase of the post-harvest shelf life for all three genotypic backgrounds.
\end{abstract}

Key words: Lycopersicon esculentum, alcobaça, ripening mutant, long shelf-life

\section{O ALELO ALCOBAÇA E O BACKGROUND GENOTÍPICO AFETAM A PRODUTIVIDADE E A CONSERVAÇÃO DE HÍBRIDOS DE TOMATEIRO}

\begin{abstract}
RESUMO: A vida de prateleira dos frutos de tomate pode ser extendida, seja empregando-se alelos mutantes que afetam o processo natural de amadurecimento, seja por meio de background genotípico favorável. O alelo alcobaça $($ alc $)$ em heterozigose tem-se mostrado bastante eficiente no sentido de prolongar o período de conservação dos frutos em pós-colheita, sem que ocorra prejuízo na coloração. Avaliaram-se os efeitos do alelo alcobaça em heterozigose $\left(a l c^{+} / a l c\right)$ sobre as características de produção e qualidade pós-colheita de frutos de híbridos de tomateiro em diferentes backgrounds genotípicos. Foram avaliados três pares de híbridos, obtidos a partir de cruzamentos entre as linhagens quase isogênicas Flora-Dade $\left(\mathrm{alc}^{+} / \mathrm{alc}^{+}\right)$e TOM-559 (alc/alc) e três diferentes linhagens maternas (Stevens, NC8276 e Piedmont), correspondendo a uma combinação fatorial de duas constituições genotípicas no loco alcobaça $\left(\right.$ alc $^{+} / a l c$ e alc $\left.^{+} / \mathrm{alc}^{+}\right)$vs três backgrounds genotípicos. Os frutos foram colhidos no estádio breaker de maturação e armazenados em câmara fria a $21^{\circ} \mathrm{C}$, durante 14 dias. Foram avaliadas características de produção e de qualidade. Independentemente da linhagem materna dos híbridos, o alelo alcobaça em heterozigose não interferiu nas características produção total, produção comercial, massa média por fruto, massa média por fruto comercial, formato do fruto e diâmetro da cicatriz peduncular dos frutos. O genótipo alc ${ }^{+} / a l c$ promoveu redução na taxa de perda de firmeza ao longo do tempo de armazenamento e retardou a taxa de evolução da coloração vermelha dos frutos. O genótipo alc ${ }^{+} /$alc contribuiu para aumentar a vida pós-colheita dos frutos de tomateiro, com efeitos similares em todas as constituições genotípicas utilizadas.

Palavras-chave: Lycopersicon esculentum, alcobaça, mutante de amadurecimento, tomate longa-vida
\end{abstract}

\section{INTRODUCTION}

Tomatoes (Lycopersicon esculentum Mill.) are grown throughout Brazil and rank as second in order of economic importance among the most consumed vegetables in the country (Filgueira, 2000). However, the to- 
mato is a product that experiences great post-harvest losses because of its natural perishability, precarious transportation and storage conditions, and inadequate packaging. In an attempt to minimize these problems, the use of mutant alleles that interfere with the fruits natural ripening process has been investigated (Hobson, 1967; Tigchelaar, 1978; Robinson \& Tomes, 1968; McGlasson et al., 1975; Tigchelaar et al., 1973; Ng \& Tigchelaar, 1977; Mutschler et al., 1992). In the 1990's, the cultivation of tomatoes of the extra-firm and long shelf-life types showed increase estimates above $50 \%$. This increase happened because of improvements in the quality of fruits considered as firm, which remained suitable for consumption for an extended period of time after being harvested. This material bears genetic traits which interfere with the activity of enzymes that act directly upon the physiological processes related to fruit maturation (Vilas Boas, 1998). These physiological processes can be altered by mutant alleles which, in heterozygosity, extend the post-harvest life of fruits. This is reflected as a higher resistance to transportation and as a longer shelf-life, without loss of their organoleptic characteristics.

Recent studies with the alcobaça (alc) gene, a mutant involved in the ripening process of tomato plant fruits, have allowed an understanding about some effects that it causes on the quality and post-harvest conservation traits of tomatoes. The effects of the alc allele on several plant and fruit traits were studied by Mutschler et al. (1992), Flori (1993), Flori \& Maluf (1994), Resende (1995), Souza (1995), Freitas (1996), and Faria (2000). However, the possible effects of the genetic background were not prioritized in these studies, even though studies previously conducted have shown that losses in fruit mass, coloration and firmness could be result from the genetic background utilized (Freitas et al., 1998). Therefore, cultivars with multilocular fruits exhibiting normal maturation pattern can be firm, as in the Flora Dade cultivar, or less firm, as in hybrids Ogata Fukuju, Sunjay, and other open pollination cultivars (Freitas et al., 1998). Two strategies, independent and not mutually exclusive, can be utilized to increase fruit firmness: the use of genetic backgrounds that condition for firm fruits and the use of mutant ripening alleles in heterozygosity (in $\mathrm{F}_{1}$ hybrids). The objective of this work was to quantify the effects from allele alc in heterozygosity on the production and post-harvest conservation traits of tomato plant fruits, and to determine whether these effects depend upon the genetic background utilized.

\section{MATERIAL AND METHODS}

Three pairs of tomato hybrids that varied with regard to their maternal line backgrounds were obtained: $\mathrm{F}_{1}$ (Stevens x Flora Dade) and $\mathrm{F}_{1}($ Stevens x TOM-559);
$\mathrm{F}_{1}\left(\mathrm{NC} 8276 \times\right.$ Flora Dade) and $\mathrm{F}_{1}(\mathrm{NC} 8276 \times \mathrm{TOM}-559)$; $\mathrm{F}_{1}$ (Piedmont $\mathrm{x}$ Flora Dade) and $\mathrm{F}_{1}$ (Piedmont $\mathrm{x}$ TOM-559). In each par, the hybrids were almost isogenic, except for the alcobaça locus, with one of them being normal $\left(\mathrm{alc}^{+}\right)$ $\left.a l c^{+}\right)$and the other heterozygous $\left(a l c^{+} / a l c\right)$. The almostisogenicity between hybrids of the same pair is due to the fact that both the paternal parental line Flora Dade $\left(\mathrm{alc}^{+} /\right.$ $a l c^{+}$) and TOM-559 (alc/alc) share a common genetic background, and TOM-559 is a line that is almost isogenic to FloraDade. The six hybrids which were tested corresponded to the factorial combination of 2 different genotypic makeups in the alcobaça locus $\left(\mathrm{alc}^{+} / \mathrm{alc}\right.$ and alc $c^{+} / a l c^{+}$) with 3 different genetic backgrounds, resulting from the different maternal lines utilized.

The experiment was installed and conducted in Lavras, MG, Brazil, during 1997 and 1998. The experimental hybrids were grown in a plastic greenhouse, in a random block design with four replications. Each plot consisted of a single row $15 \mathrm{~m}$ in length, with a total of 30 plants. The plants were grown on a half-stake tutored system and were drip-irrigated, using double rows, spaced $0.9 \mathrm{~m}$ between seedbeds, $0.6 \mathrm{~m}$ between rows in the seedbed and 0.50 between plants. Weeding, fertilization, irrigation and phytosanitary control operations were performed following ecommendations for growing tomato plants of the salad group in greenhouses (Cermeño, 1988).

Fifteen harvests were performed and the following traits were evaluated: total yield, commercial production, early commercial production (corresponding to the first five harvests), mean mass per fruit, mean mass per commercial fruit, relative diameter of the pedicel scar (ratio between scar diameter and fruit diameter), and shape [ratio between fruit length (L) and diameter (D), where the measurement relations $\mathrm{L} / \mathrm{D}<1, \mathrm{~L} / \mathrm{D}=1$ and $\mathrm{L} / \mathrm{D}>1$ correspond to shapes flat, round and oblong, respectively].

In order to assess the firmness and coloration traits, ten fruits were sampled per plot ( 5 from the $1^{\text {st }}$ cluster and 5 from the $3^{\text {rd }}$ cluster), harvested at the breaker ripening stage. After harvesting, the fruits remained in cold storage at $21^{\circ} \mathrm{C}$ and $60 \%$ relative humidity, during the entire evaluation period. Firmness was determined by the applanation method proposed by Calbo \& Nery (1995), with fruits being evaluated over a 14-day period, at two-day intervals.

To evaluate evolution of fruit color, the number of days elapsed from sowing to fruit harvest was initially calculated at the breaker stage. The five fruits sampled from each cluster, in each plot, that were harvested at the breaker stage (score 1), received individual grades daily, during eight consecutive days under storage, according to their external coloration, within a scale that ranged from 1 to 5, as follows: 1 = fruits beginning to show a red coloration in the apical end (breaker stage); 2 = fruits showing from $20 \%$ to $40 \%$ of their surface area with a 
red color; 3 fruits showing from $40 \%$ to $60 \%$ of their surface area with a red color; $4=$ fruits showing from $60 \%$ to $80 \%$ of their surface area with a red color; $5=$ fruits showing more than $80 \%$ of their surface area with a red color.

The score for each plot was considered as the mean of scores given to fruits of that plot in each day. The number of days elapsed to reach the pink, pale red, and red maturation stages, from the breaker stage, was also calculated for each fruit. Stages pink, pale red and red corresponded to coloration scores 2, 3 and 4, respectively. Data were expressed at the plot mean level.

Analyses of variance of collected data were performed for the traits under evaluation. Treatment means were compared using Duncan test $(\alpha=0.05)$. Non-orthogonal contrasts involving the almost-isogenic pairs of hybrids were calculated to assess the effects of the $\mathrm{alc}^{+} /$ alc locus on the traits being evaluated. Regression models were utilized to adjust the course of evolution of coloration and loss of fruit firmness along time. For the first trait, a logistic model was adjusted: $Y=A /\left(1+B^{*} R^{X}\right)$, where $X$ is the number of days elapsed after harvesting the fruits (at breaker stage); $Y$ is the evolution of coloration in the fruits (as measured by grades 1 to 5); $A, B$ and $R$ are parameters of the model. In the second case, the firmness half-life (that corresponds to the number of days, since harvesting for the fruit firmness to be reduced to half the initial value), was calculated. The firmness halflife $(T)$ was obtained by regression of firmness data $(A)$ from each plot in the number of days elapsed $(X)$, by the exponential decay statistical model: $A=A_{0} *(1 / 2)^{X / \mathrm{T}}$, where $A_{0}$ is the initial fruit firmness in the breaker stage; $X$ is the number of days elapsed after harvest in the breaker stage; $T$ is the firmness half-life; $A$ is the firmness after $X$ days have elapsed.

Curves were calculated with a feature from a statistical package (SAS Institute, 1990), by using the NLIN procedure for the logistic model, which is appropriate to adjust non-linear models; for the exponential decay model, the log transform followed by linear regression was utilized. The values obtained for fruit firmness, along the time elapsed after harvest, were adjusted to the exponential decay model previously mentioned. Based on the adjusted equation, the following determinations were made for each plot: initial fruit firmness in the breaker stage $\left(A_{0}\right)$; firmness half-life $(T)$; number of days elapsed for the fruits to attain firmnesses of $4.0 \times 10^{4} \mathrm{~N} \mathrm{~m}^{-2}, 3.0$ $\mathrm{x} 10^{4} \mathrm{~N} \mathrm{~m}^{-2}, 2.5 \times 10^{4} \mathrm{~N} \mathrm{~m}^{-2}$ and $2.0 \times 10^{4} \mathrm{~N} \mathrm{~m}^{-2}$.

\section{RESULTS AND DISCUSSION}

Hybrids attained a total mean yield of $72.38 \mathrm{t} \mathrm{ha}^{-1}$ and did not show differences among themselves. There were no effects of either alcobaça makeup or of the ma- ternal lines utilized, or of the interaction between these two factors. Contrasts involving the hybrids under assessment were non-significant for yield, indicating that the alc allele, in heterozygosity, did not affect total yield, regardless of hybrid maternal line. With regard to commercial production, no differences occurred between the hybrids being assessed, regardless of the alcobaça locus makeup and of the maternal line deployed (Table 1).

The heterozygous hybrids for the alcobaça locus $($ alc $/$ alc $)$ showed an early commercial production mean of $7.68 \mathrm{t} \mathrm{ha}^{-1}$. This value was lower than the mean for normal hybrids $\left(\right.$ alc $^{+} /$alc $\left.^{+}\right), 12.87 \mathrm{t} \mathrm{ha}^{-1}$, i.e., the alcobaça mutant allele in heterozygosity caused a mean reduction of $40.32 \%$ in the early commercial production of fruits (Table 1). These results confirm the effect of genotype alc ${ }^{+} /$alc in delaying attainment of the breaker stage, therefore keeping the fruits in the plant for a longer period, and reducing early harvests, since coloration is what indicates harvest time. The negative effect of the alcobaça allele in heterozygosity on earliness was also recorded by Freitas (1996) and Faria (2000). No differences were detected in maternal genetic background effect on the earliness of the commercial production of hybrids, or in as its interaction with the alcobaça locus makeup. However, a tendency was observed for the Stevens maternal line in reducing the early commercial production, even in the normal hybrid for the alcobaça locus $\left(\right.$ alc $^{+} /$alc $\left.^{+}\right)$. That could explain why differences between alc $^{+} / \mathrm{alc}^{+}$and $\mathrm{alc}^{+} /$ alc for early production were not detected with this background.

In general, the experimental hybrids showed differences with regard to mean fruit mass, varying in accordance to the background utilized, with values ranging from $134.3 \mathrm{~g}$ for $\mathrm{F}_{1}$ hybrid (Stevens $\mathrm{x}$ Flora Dade) to $165.0 \mathrm{~g}$ for $\mathrm{F}_{1}$ hybrid (Piedmont $\mathrm{x}$ Flora Dade). The mutant allele alc in heterozygosity $($ alc $/$ alc) did not affect the mean mass per fruit, regardless of the hybrid's maternal line background (Table 1), since the interaction genotypic makeup $\mathrm{x}$ background was non-significant.

Mutschler et al. (1992), Souza (1995), Freitas (1996), and Faria (2000) concluded that the mean fruit mass is not affected by the genotypic makeup of the alcobaça locus, in agreement with the results of this paper. The mean mass per commercial fruit was not affected by the alcobaça allele in heterozygosity: the general mean for the three alc $/$ alc hybrids, was comparable to the mean of their normal isogenic counterparts $\left(\mathrm{alc}^{+} / \mathrm{alc}^{+}\right)$, and there was no interaction with the hybrids' maternal line background, even though the mean mass per commercial fruit varied depending on the utilized background (Table 1) and, in the case of the Piedmont maternal line background, the contrast between $a l c^{+} /$alc and alc $^{+} /$alc $^{+}$was detected as significant. 
Table 1 - Total yield, commercial production, early commercial production, mean mass per fruit, mean mass per commercial fruit and non-orthogonal contrasts of interest in six tomato plant hybrids assessed through an experiment carried out in plastic greenhouse.

\begin{tabular}{|c|c|c|c|c|c|c|}
\hline & & Total yield & $\begin{array}{c}\text { Commercial } \\
\text { yield }\end{array}$ & $\begin{array}{c}\text { Early } \\
\text { commercial }\end{array}$ & $\begin{array}{l}\text { Average fruit } \\
\text { mass }\end{array}$ & $\begin{array}{l}\text { Average commercial } \\
\text { fruit mass }\end{array}$ \\
\hline & & \multicolumn{3}{|c|}{ - } & \multicolumn{2}{|c|}{ - } \\
\hline \multirow[t]{2}{*}{ Genotipic nature of Alcobaça locus } & $\begin{array}{l}\text { alc }^{+} / \text {alc }^{+} \\
\text {(normal) }\end{array}$ & $77.86 \mathrm{a}^{11}$ & $74.30 \mathrm{a}$ & $12.87 \mathrm{a}$ & $152.7 \mathrm{a}$ & $158.8 \mathrm{a}$ \\
\hline & alc $c^{+} /$alc & $66.90 \mathrm{a}$ & $63.59 \mathrm{a}$ & $7.68 \mathrm{~b}$ & $143.7 \mathrm{a}$ & $151.6 \mathrm{a}$ \\
\hline \multirow[t]{3}{*}{ Background of the maternal line } & Stevens & $80.31 \mathrm{a}$ & $75.64 \mathrm{a}$ & $7.81 \mathrm{a}$ & $135.4 \mathrm{~b}$ & $141.5 \mathrm{~b}$ \\
\hline & NC8276 & $73.19 \mathrm{a}$ & $70.21 \mathrm{a}$ & $11.36 \mathrm{a}$ & $152.3 \mathrm{a}$ & $159.8 \mathrm{a}$ \\
\hline & Piedmont & $63.64 \mathrm{a}$ & $61.00 \mathrm{a}$ & $11.63 \mathrm{a}$ & $156.9 \mathrm{a}$ & $164.4 \mathrm{a}$ \\
\hline Hybrids & Genotypes & & & & & \\
\hline F1(Stevens x Flora Dade) & Normal & $86.98 \mathrm{a}$ & $81.49 \mathrm{a}$ & $8.82 \mathrm{~b}$ & $134.3 \mathrm{~b}$ & $140.8 \mathrm{~b}$ \\
\hline F1(Stevens x TOM-559) & alc $c^{+} / a l c$ & $73.64 \mathrm{a}$ & $69.79 \mathrm{a}$ & $6.87 \mathrm{~b}$ & $136.5 \mathrm{~b}$ & $142.3 \mathrm{~b}$ \\
\hline F1(NC8276x Flora Dade) & Normal & $68.59 \mathrm{a}$ & $66.07 \mathrm{a}$ & $14.44 \mathrm{a}$ & $158.3 \mathrm{a}$ & $163.0 \mathrm{a}$ \\
\hline F1(NC8276 x TOM-559) & alc $c^{+} / a l c$ & $58.69 \mathrm{a}$ & $55.92 \mathrm{a}$ & $8.28 \mathrm{~b}$ & $146.3 \mathrm{ab}$ & $156.5 \mathrm{ab}$ \\
\hline F1(Piedmont x Flora Dade) & Normal & $78.01 \mathrm{a}$ & $75.35 \mathrm{a}$ & $15.37 \mathrm{a}$ & $165.0 \mathrm{a}$ & $172.8 \mathrm{a}$ \\
\hline F1(Piedmont x TOM-559) & alc ${ }^{+} / a l c$ & $68.37 \mathrm{a}$ & $65.07 \mathrm{a}$ & $7.90 \mathrm{~b}$ & $148.3 \mathrm{ab}$ & $156.0 \mathrm{ab}$ \\
\hline \multirow{2}{*}{\multicolumn{2}{|c|}{ Contrasts of interest }} & \multicolumn{5}{|c|}{ Estimatives } \\
\hline & & \multicolumn{3}{|c|}{ - } & \multicolumn{2}{|c|}{ - } \\
\hline \multicolumn{2}{|c|}{$\begin{array}{l}\text { alc } c^{+} / \text {alc vs alc }{ }^{+} / a l c^{+} \text {in hybrids with Stevens } \\
\text { maternal line }\end{array}$} & $-13.34^{\mathrm{ns}}$ & $-11.70^{\mathrm{ns}}$ & $-1.95^{\mathrm{ns}}$ & $2.2^{\mathrm{ns}}$ & $1.5^{\mathrm{ns}}$ \\
\hline \multicolumn{2}{|c|}{$\begin{array}{l}\text { alc } c^{+} / \text {alc } v s \text { alc } c^{+} / \text {alc }^{+} \text {in hybrids with } \mathrm{NC} 8276 \\
\text { maternal line }\end{array}$} & $-9.90^{\mathrm{ns}}$ & $-10.15^{\mathrm{ns}}$ & $-6.16^{*}$ & $-12.0^{\mathrm{ns}}$ & $-6.5^{\mathrm{ns}}$ \\
\hline \multicolumn{2}{|c|}{$\begin{array}{l}\text { alc } c^{+} \text {alc vs } \text { alc }^{+} / \text {alc }^{+} \text {in hybrids with Piedmont } \\
\text { maternal line }\end{array}$} & $-9.65^{\mathrm{ns}}$ & $-10.29^{\text {ns }}$ & $-7.47 * *$ & $-17.3^{\mathrm{ns}}$ & $-16.8 *$ \\
\hline
\end{tabular}

${ }^{11}$ Means followed by a common letter are not different by Duncan test $(\alpha=0.05)$.

**, *Significant at $1 \%$ and $5 \%$, respectively, by $\mathrm{F}$ test.

With respect to the relative diameter of the pedicel scar and shape of fruits, differences were observed between the maternal line backgrounds. With regard to the genotypic makeups in the alcobaça locus, no differences were detected between heterozygous $\left(\right.$ alc $\left.{ }^{+} / a l c\right)$ and normal $\left(a l c^{+} /\right.$alc $\left.^{+}\right)$hybrid means for these two traits, in fruits from both clusters (Table 2).

The fruits were assessed with respect to their firmness on the day of harvest (breaker stage), and the genotypes did not behave in a differentiated manner (Table 2). From this initial evaluation there was an exponential decrease in fruit firmness as they would ripen. Differences in half-life occurred between the hybrids under evaluation, and both the alcobaça locus makeup and the maternal line background effects on this trait were observed. Once again no mean effect of the interaction was detected. In general, fruits from the first and third clusters of heterozygous hybrids in the alcobaça locus showed an average increase of approximately 3 days in firmness half-life, as compared to normal isogenic hybrids (Table 2). However, the increase in firmness half-life resulting from the background effect was independent from that obtained with the use of the alc ${ }^{+} /$alc genotypic makeup. Therefore, the genotypic background can be manipulated in addition to using the alc ripening mutant, to promote increased shelf life of fruits.
Just like for the initial firmness trait, no effect of the makeups in the alcobaça locus on the mean number of days for the fruits to attain $4.0 \times 10^{4} \mathrm{~N} \mathrm{~m}^{-2}$ was observed. This value is close to that recorded for initial firmness (Table 3). However, as the storage time progressed, the alc allele in heterozygosity started to function favorably, de-accelerating fruit firmness loss (Table 3). The alc ${ }^{+}$alc makeup was responsible for an average increase of 1.9 and 2.5 days for the fruits from the first and third clusters, respectively, to attain firmness of $3.0 \times 10^{4} \mathrm{~N}$ $\mathrm{m}^{-2}$. As firmness decreased, the $a l c^{+} /$alc locus effect was even more pronounced, and the average increase was 2.5 and 3.2 days for the fruits of the first and third clusters, respectively, to attain firmness of $2.5 \times 10^{4} \mathrm{~N} \mathrm{~m}^{-2}$ and, similarly, 3.4 and 4.1 days to attain firmness of $2.0 \times 10^{4}$ $\mathrm{N} \mathrm{m}^{-2}$. This advantage of the heterozygous hybrids in the alcobaça locus as compared to normal hybrids is quite significant from a post-harvest conservation standpoint, and characterizes the so-called long shelf-life tomatoes. With respect to the effect of the maternal line background on the number of days for the fruits to attain the four stipulated levels of firmness, the superiority in performance of line NC8276 became evident, reducing, for its hybrids, the fruit rate of loss of firmness along the storage time. When compared to their normal counterparts $\left(\mathrm{alc}^{+} / \mathrm{alc}^{+}\right)$, the heterozygous hybrids in the alcobaça locus showed a 
Table 2 - Relative diameter of pedicel scar, length/width ratio (shape of fruit), initial firmness (at breaker stage) and fruit firmness half-life, and non-orthogonal contrasts of interest in six tomato plant hybrids.

\begin{tabular}{|c|c|c|c|c|c|c|c|c|c|}
\hline & & \multicolumn{2}{|c|}{$\begin{array}{l}\text { Relative diameter of } \\
\text { pedicel scar }\end{array}$} & \multicolumn{2}{|c|}{$\begin{array}{l}\text { Relative length/ width ratio } \\
\text { (fruit shape) }\end{array}$} & \multicolumn{2}{|c|}{ Initial firmness } & \multicolumn{2}{|c|}{ Fruit firmness } \\
\hline & & Cluster 1 & Cluster 3 & Cluster 1 & Cluster 3 & Cluster 1 & Cluster 3 & Cluster 1 & Cluster 3 \\
\hline & & & & & & $---\times 10^{4}$ & ${ }^{4} \mathrm{~N} \mathrm{~m}^{-2}-\cdots-$ & $-\ldots-d a$ & S -.-.-.- \\
\hline \multirow[t]{2}{*}{$\begin{array}{l}\text { Genotipic nature of } \\
\text { Alcobaça locus }\end{array}$} & $\begin{array}{l}\text { alc }^{+} / \text {alc }^{+} \\
\text {(normal) }\end{array}$ & $0.2089 \mathrm{a}^{11}$ & $0.2155 \mathrm{a}$ & $0.7974 \mathrm{a}$ & $0.7785 \mathrm{a}$ & $4.7533 \mathrm{a}$ & $4.6175 \mathrm{a}$ & $7.8 \mathrm{~b}$ & $9.0 \mathrm{~b}$ \\
\hline & alc $c^{+} / a l c$ & $0.1924 \mathrm{a}$ & $0.2117 \mathrm{a}$ & $0.7975 \mathrm{a}$ & $0.7888 \mathrm{a}$ & $4.8625 \mathrm{a}$ & $4.7475 \mathrm{a}$ & $10.5 \mathrm{a}$ & $11.8 \mathrm{a}$ \\
\hline \multirow[t]{3}{*}{$\begin{array}{l}\text { Background of the } \\
\text { maternal line }\end{array}$} & Stevens & $0.2248 \mathrm{a}$ & $0.2401 \mathrm{a}$ & $0.8093 \mathrm{a}$ & $0.8140 \mathrm{a}$ & $4.5850 \mathrm{a}$ & 4.7488 a & $9.5 \mathrm{a}$ & $9.1 \mathrm{~b}$ \\
\hline & NC8276 & $0.1814 \mathrm{~b}$ & $0.1943 \mathrm{~b}$ & $0.7708 \mathrm{~b}$ & $0.7559 \mathrm{~b}$ & $4.7500 \mathrm{a}$ & $4.8913 \mathrm{a}$ & $9.6 \mathrm{a}$ & $12.0 \mathrm{a}$ \\
\hline & Piedmont & $0.1959 \mathrm{~b}$ & $0.2064 \mathrm{~b}$ & $0.8124 \mathrm{a}$ & $0.7811 \mathrm{~b}$ & $5.0888 \mathrm{a}$ & $4.4075 \mathrm{a}$ & $8.3 \mathrm{a}$ & $10.1 \mathrm{ab}$ \\
\hline Hybrids & Genotypes & & & & & & & & \\
\hline F1(Stevens x Flora Dade) & Normal & $0.2385 \mathrm{a}$ & $0.2383 \mathrm{a}$ & $0.8013 \mathrm{ab}$ & $0.8160 \mathrm{a}$ & $4.5175 \mathrm{a}$ & $4.8175 \mathrm{a}$ & $8.0 \mathrm{bc}$ & $8.3 \mathrm{~b}$ \\
\hline F1(Stevens x TOM-559) & alc + alc & $0.2110 \mathrm{ab}$ & $0.2420 \mathrm{a}$ & $0.8173 \mathrm{a}$ & $0.8120 \mathrm{a}$ & $4.6525 \mathrm{a}$ & $4.6800 \mathrm{a}$ & $11.0 \mathrm{ab}$ & $9.9 \mathrm{~b}$ \\
\hline F1(NC8276x Flora Dade) & Normal & $0.1900 \mathrm{bc}$ & $0.1930 \mathrm{~b}$ & $0.7725 \mathrm{~b}$ & $0.7400 \mathrm{~b}$ & $4.9525 \mathrm{a}$ & $4.8725 \mathrm{a}$ & $7.9 \mathrm{c}$ & $8.9 \mathrm{~b}$ \\
\hline F1(NC8276 x TOM-559) & alc $c^{+} / a l c$ & $0.1728 \mathrm{c}$ & $0.1955 \mathrm{~b}$ & $0.7690 \mathrm{~b}$ & $0.7718 \mathrm{ab}$ & $4.5475 \mathrm{a}$ & $4.9100 \mathrm{a}$ & $11.3 \mathrm{a}$ & $15.1 \mathrm{a}$ \\
\hline $\begin{array}{l}\text { F1(Piedmont x Flora } \\
\text { Dade) }\end{array}$ & Normal & $0.1983 \mathrm{bc}$ & $0.2038 \mathrm{~b}$ & 0.8185 a & $0.7795 \mathrm{ab}$ & $4.7900 \mathrm{a}$ & $4.1625 \mathrm{a}$ & $7.5 \mathrm{c}$ & $9.7 \mathrm{~b}$ \\
\hline F1(Piedmont x TOM-559) & alc + alc & $0.1935 \mathrm{bc}$ & $0.2090 \mathrm{~b}$ & $0.8063 \mathrm{ab}$ & $0.7828 \mathrm{ab}$ & $5.3875 \mathrm{a}$ & $4.6525 \mathrm{a}$ & $9.1 \mathrm{abc}$ & $10.4 \mathrm{~b}$ \\
\hline \multirow{2}{*}{\multicolumn{2}{|c|}{ Contrast of interest }} & \multicolumn{8}{|c|}{ Estimates } \\
\hline & & & & & & $---\times 10^{4}$ & ${ }^{4} \mathrm{~N} \mathrm{~m}^{-2}-\cdots$ & $-\ldots---d a$ & $y-\cdots--$ \\
\hline \multicolumn{2}{|c|}{$\begin{array}{l}\text { alc } c^{+} / a l c \text { vs alc }{ }^{+} / a l c^{+} \text {in hybrids with } \\
\text { Stevens maternal line }\end{array}$} & $-0.0275^{\mathrm{ns}}$ & $0.0037^{\mathrm{ns}}$ & $0.0160^{\mathrm{ns}}$ & $-0.0040^{\mathrm{ns}}$ & $0.1350^{\mathrm{ns}}$ & $-0.1375^{\mathrm{ns}}$ & $3.0^{*}$ & $1.6^{\mathrm{ns}}$ \\
\hline \multicolumn{2}{|c|}{$\begin{array}{l}\text { alc } c^{+} / \text {alc } \text { vs } \text { alc }^{+} / \text {alc } \\
\text { NC } 8276 \text { maternal line }\end{array}$} & $-0.0172^{\mathrm{ns}}$ & $0.0025^{\text {ns }}$ & $-0.0035^{\mathrm{ns}}$ & $0.0318^{\mathrm{ns}}$ & $-0.4050^{\mathrm{ns}}$ & $0.0375^{\mathrm{ns}}$ & $3.4 *$ & $6.2 * *$ \\
\hline \multicolumn{2}{|c|}{$\begin{array}{l}\text { alc } c^{+} / a l c \text { vs } \text { alc }^{+} / \text {alc }^{+} \text {in hybrids with } \\
\text { Piedmont maternal line }\end{array}$} & $-0.0048^{\mathrm{ns}}$ & $0.0052^{\mathrm{ns}}$ & $-0.0122^{\mathrm{ns}}$ & $0.0033^{\mathrm{ns}}$ & $0.5975^{\text {ns }}$ & $0.4900^{\mathrm{ns}}$ & $1.6^{\mathrm{ns}}$ & $0.7^{\text {ns }}$ \\
\hline
\end{tabular}

${ }^{\prime \prime}$ Means followed by a common letter are not different by Duncan test $(\alpha=0.05)$.

**, * Significant at $1 \%$ and $5 \%$, respectively, by $\mathrm{F}$ test.

commercial extended shelf life between 1.8 and 8.2 day time necessary to attain a firmness degree of $2.0 \times 10^{4} \mathrm{~N}$ $\mathrm{m}^{2}$, at which they were considered as non-marketable (Table 3).

The intervals between sowing and the breaker stage (harvest day) and between breaker stage and the consecutive fruit coloration stages (pink, pale red and red) were evaluated (Table 4). A genotypic makeup effect in the alcobaça locus was observed for the number of days from sowing to harvest in the breaker stage, only for fruits in the first cluster.

On the other hand, no differences were detected for the maternal line effect or for their interaction with the genotypic makeups in the alcobaça locus, in fruits from both clusters. Therefore, there is an indication that the harvest delay effect (i.e., breaker stage) in alc ${ }^{+} /$alc genotypes relatively to $\mathrm{Ilc}^{+} / \mathrm{alc}^{+}$, is independent from the background under consideration. The treatments showed significant differences, detected by Duncan test $(\alpha=0.05)$, relative to the after-harvest evolution in fruit coloration, and the highest means were attained by hybrids bearing the alc $^{+} /$alc locus, which, in general, evolved more slowly to an intense red coloration (Table 4). Fruits from both clusters of hybrids alc ${ }^{+}$alc took, on average, 1.3 and 1.8 days longer than the mean of hybrids alc $^{+} /$alc $^{+}$to attain the pink and pale red stages, respectively. To attain the red stage, however, fruits of hybrids alc $/$ alc showed a delay of 3.7 and 4.0 days for fruits in the first and third clusters, respectively. The positive-value estimates of contrasts that compare pairs of isogenic hybrids confirm the alcobaça locus effects in heterozygosity toward delaying the post-harvest evolution of coloration in the fruits. This delay in the evolution of coloration of fruits ascribed to the alc ${ }^{+} /$alc locus agrees with experimental results obtained by Souza (1995), Freitas (1996), Araújo (1997), Freitas et al. (1998), and Faria (2000). The slower coloration evolution is an unfavorable aspect, although non-limiting, from the consumer preference viewpoint. To increase the red color in alc $/$ alc fruits and make them more attractive, Faria (2000) suggests the joint incorporation of mutant alleles $h p$ (high pigment) and $\operatorname{og}^{c}$ (crimson), in the heterozygous condition, in hybrids that are heterozygous for the alcobaça locus.

\section{CONCLUSIONS}

The utilization of the alcobaça mutant in heterozygosity $\left(\right.$ alc $^{+} /$alc $)$decreased fruit firmness loss in tomato plants. The alc $/$ alc locus effects observed in the hybrids for the traits being assessed did not interact with the hybrid's maternal line background, indicating that the 
Table 3 - Mean number of days for the fruits to attain firmnesses of $4.0 \times 10^{4} \mathrm{~N} \mathrm{~m}^{-2}, 3.0 \times 10^{4} \mathrm{~N} \mathrm{~m}^{-2}, 2.5 \times 10^{4} \mathrm{~N} \mathrm{~m}^{-2}$ and $2.0 \times 10^{4}$ $\mathrm{N} \mathrm{m}^{-2}$, and non-orthogonal contrasts of interest in six tomato plant hybrids.

\begin{tabular}{|c|c|c|c|c|c|c|c|c|c|}
\hline & & \multicolumn{2}{|c|}{$\begin{array}{l}\text { Number of days for the } \\
\text { fruits to attain firmnesses }\end{array}$} & \multicolumn{2}{|c|}{$\begin{array}{l}\text { Number of days for the } \\
\text { fruits to attain firmnesses }\end{array}$} & \multicolumn{2}{|c|}{$\begin{array}{l}\text { Number of days for } \\
\text { the fruits to attain } \\
\text { firmnesses }\end{array}$} & \multicolumn{2}{|c|}{$\begin{array}{l}\text { Number of days for } \\
\text { the fruits to attain } \\
\text { firmnesses }\end{array}$} \\
\hline & & Cluster 1 & Cluster 3 & Cluster 1 & Cluster 3 & Cluster 1 & Cluster 3 & Cluster 1 & Cluster 3 \\
\hline & & \multicolumn{2}{|c|}{$4.0 \times 10^{4} \mathrm{~N} \mathrm{~m}^{-2}$} & \multicolumn{2}{|c|}{$3.0 \times 10^{4} \mathrm{~N} \mathrm{~m}^{-2}$} & \multicolumn{2}{|c|}{$2.5 \times 10^{4} \mathrm{~N} \mathrm{~m}^{-2}$} & \multicolumn{2}{|c|}{$2.0 \times 10^{4} \mathrm{~N} \mathrm{~m}^{-2}$} \\
\hline \multirow[t]{2}{*}{$\begin{array}{l}\text { Genotipic nature of } \\
\text { Alcobaça locus }\end{array}$} & $\begin{array}{l}\text { alc }^{+} / a l c^{+} \\
\text {(normal) }\end{array}$ & $1.8 \mathrm{a}^{11}$ & $1.6 \mathrm{a}$ & $5.0 \mathrm{~b}$ & $5.3 \mathrm{~b}$ & $7.1 \mathrm{~b}$ & $7.7 \mathrm{~b}$ & $9.6 \mathrm{~b}$ & $10.6 \mathrm{~b}$ \\
\hline & alc $c^{+}$alc & $2.5 \mathrm{a}$ & $2.9 \mathrm{a}$ & $6.9 \mathrm{a}$ & $7.8 \mathrm{a}$ & $9.6 \mathrm{~A}$ & $10.9 \mathrm{a}$ & $13.0 \mathrm{a}$ & $14.7 \mathrm{a}$ \\
\hline \multirow[t]{3}{*}{$\begin{array}{l}\text { Background of the } \\
\text { maternal line }\end{array}$} & Stevens & $1.7 \mathrm{a}$ & $2.0 \mathrm{ab}$ & $5.7 \mathrm{a}$ & $5.8 \mathrm{~b}$ & $8.2 \mathrm{a}$ & $8.2 \mathrm{~b}$ & $11.2 \mathrm{a}$ & $11.1 \mathrm{~b}$ \\
\hline & NC8276 & $1.9 \mathrm{a}$ & $3.5 \mathrm{a}$ & $5.9 \mathrm{a}$ & $8.5 \mathrm{a}$ & $8.4 \mathrm{a}$ & $11.6 \mathrm{a}$ & $11.5 \mathrm{a}$ & $15.5 \mathrm{a}$ \\
\hline & Piedmont & $2.8 \mathrm{a}$ & $1.1 \mathrm{~b}$ & $6.3 \mathrm{a}$ & $5.3 \mathrm{~b}$ & $8.4 \mathrm{a}$ & $8.0 \mathrm{~b}$ & $11.1 \mathrm{a}$ & $11.2 \mathrm{~b}$ \\
\hline Hybrids & Genotypes & & & & & & & & \\
\hline F1(Stevens x Flora Dade) & Normal & $1.2 \mathrm{~b}$ & $1.9 \mathrm{~b}$ & $4.5 \mathrm{c}$ & $5.4 \mathrm{~b}$ & $6.7 \mathrm{~b}$ & $7.6 \mathrm{~b}$ & $9.2 \mathrm{c}$ & $10.2 \mathrm{~b}$ \\
\hline F1(Stevens x TOM-559) & alc $+/ a l c$ & $2.2 \mathrm{ab}$ & $2.1 \mathrm{ab}$ & $6.8 \mathrm{ab}$ & $6.2 \mathrm{~b}$ & $9.7 \mathrm{a}$ & $8.8 \mathrm{~b}$ & $13.2 \mathrm{a}$ & $12.0 \mathrm{~b}$ \\
\hline F1(NC8276x Flora Dade) & Normal & $2.3 \mathrm{ab}$ & $2.5 \mathrm{ab}$ & $5.6 \mathrm{abc}$ & $6.2 \mathrm{~b}$ & $7.7 \mathrm{ab}$ & $8.6 \mathrm{~b}$ & $10.2 \mathrm{bc}$ & $11.4 \mathrm{~b}$ \\
\hline F1(NC8276 x TOM-559) & $a l c^{+} / a l c$ & $1.5 \mathrm{ab}$ & $4.5 \mathrm{a}$ & $6.2 \mathrm{abc}$ & $10.8 \mathrm{a}$ & $9.2 \mathrm{a}$ & $14.7 \mathrm{a}$ & $12.9 \mathrm{ab}$ & $19.6 \mathrm{a}$ \\
\hline $\begin{array}{l}\text { F1(Piedmont x Flora } \\
\text { Dade) }\end{array}$ & Normal & $1.8 \mathrm{ab}$ & $0.3 \mathrm{~b}$ & $4.9 \mathrm{bc}$ & $4.3 \mathrm{~b}$ & $6.9 \mathrm{~b}$ & $6.9 \mathrm{~b}$ & $9.3 \mathrm{c}$ & $10.0 \mathrm{~b}$ \\
\hline F1(Piedmont $x$ TOM-559) & $a l c^{+} / a l c$ & $3.8 \mathrm{a}$ & $1.9 \mathrm{~b}$ & $7.6 \mathrm{a}$ & $6.3 \mathrm{~b}$ & $10.0 \mathrm{a}$ & $9.0 \mathrm{~b}$ & $12.9 \mathrm{ab}$ & $12.4 \mathrm{~b}$ \\
\hline \multirow{2}{*}{\multicolumn{2}{|c|}{ Contrast of interest }} & \multicolumn{8}{|c|}{ Estimatives } \\
\hline & & & & 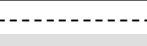 & dом & & (t) & & --.-- \\
\hline \multicolumn{2}{|c|}{$\begin{array}{l}\text { alc } c^{+} / a l c \text { vs } a l c^{+} / a l c^{+} \text {in hybrids with } \\
\text { Stevens maternal line }\end{array}$} & $1.0^{\mathrm{ns}}$ & $0.2^{\mathrm{ns}}$ & $2.3 *$ & $0.8^{\mathrm{ns}}$ & $3.0^{*}$ & $1.2^{\mathrm{ns}}$ & $4.0 * *$ & $1.8^{\mathrm{ns}}$ \\
\hline \multicolumn{2}{|c|}{$\begin{array}{l}\text { alc } c^{+} / \text {alc } v s \text { alc } c^{+} / \text {alc }^{+} \text {in hybrids with } \\
\text { NC8276 maternal line }\end{array}$} & $-0.8^{\mathrm{ns}}$ & $2.0^{\mathrm{ns}}$ & $0.6^{\mathrm{ns}}$ & $4.6 * *$ & $1.5^{\mathrm{ns}}$ & $6.1 * *$ & $2.7^{\text {ns }}$ & $8.2 * *$ \\
\hline \multicolumn{2}{|c|}{$\begin{array}{l}\text { alc } c^{+} / \text {alc } v s \text { alc } c^{+} / a_{l} c^{+} \text {in hybrids with } \\
\text { Piedmont maternal line }\end{array}$} & $2.0^{\mathrm{ns}}$ & $1.6^{\mathrm{ns}}$ & $2.7 *$ & $2.0^{\mathrm{ns}}$ & $3.1 * *$ & $2.1^{\mathrm{ns}}$ & $3.6^{*}$ & $2.4^{\mathrm{ns}}$ \\
\hline
\end{tabular}

${ }^{1}$ Means followed by a common letter are not different by Duncan test $(\alpha=0.05)$.

**, *Significant at $1 \%$ and $5 \%$, respectively, by $\mathrm{F}$ test.

Table 4 - Mean number of days from sowing to harvest at breaker stage and mean number of days from breaker stage to pink, pale red and red fruit stages, and non-orthogonal contrasts of interest in six tomato plant hybrids.

\begin{tabular}{|c|c|c|c|c|c|c|c|c|c|}
\hline & \multicolumn{2}{|c|}{$\begin{array}{c}\text { Number of days from } \\
\text { sowing to harvest at } \\
\text { breaker stage }\end{array}$} & \multicolumn{2}{|c|}{$\begin{array}{c}\text { Number of days from } \\
\text { breaker stage } \\
\text { to pink }\end{array}$} & \multicolumn{2}{|c|}{$\begin{array}{c}\text { Number of days from } \\
\text { breaker stage to red } \\
\text { pale }\end{array}$} & \multicolumn{2}{|c|}{$\begin{array}{c}\text { Number of days from } \\
\text { breaker stage } \\
\text { to red }\end{array}$} \\
\hline & & Cluster 1 & Cluster 3 & Cluster 1 & Cluster 3 & Cluster 1 & Cluster 3 & Cluster 1 & Cluster 3 \\
\hline \multirow[t]{2}{*}{$\begin{array}{l}\text { Genotipic nature of } \\
\text { Alcobaça locus }\end{array}$} & $\begin{array}{l}\text { alc }^{+} / \text {alc }^{+} \\
\text {(normal) }\end{array}$ & $100.2 b^{11}$ & $119.1 \mathrm{a}$ & $2.0 \mathrm{~b}$ & $2.0 \mathrm{~b}$ & $4.3 \mathrm{~b}$ & $4.7 \mathrm{~b}$ & $8.1 \mathrm{~b}$ & $8.6 \mathrm{~b}$ \\
\hline & alc $c^{+} / a l c$ & $104.9 \mathrm{a}$ & $120.1 \mathrm{a}$ & $3.3 \mathrm{a}$ & $3.3 \mathrm{a}$ & $6.1 \mathrm{a}$ & $6.5 \mathrm{a}$ & $11.8 \mathrm{a}$ & $12.6 \mathrm{a}$ \\
\hline \multirow[t]{3}{*}{$\begin{array}{l}\text { Background of the } \\
\text { maternal line }\end{array}$} & Stevens & $102.3 \mathrm{ab}$ & $118.6 \mathrm{a}$ & $2.8 \mathrm{a}$ & $3.5 \mathrm{a}$ & $5.2 \mathrm{a}$ & $6.1 \mathrm{a}$ & $10.3 \mathrm{a}$ & $11.3 \mathrm{a}$ \\
\hline & NC8276 & $105.5 \mathrm{a}$ & $121.4 \mathrm{a}$ & $2.4 \mathrm{a}$ & $2.2 \mathrm{a}$ & $4.8 \mathrm{a}$ & $5.5 \mathrm{a}$ & $8.9 \mathrm{a}$ & $10.8 \mathrm{a}$ \\
\hline & Piedmont & $99.9 \mathrm{~b}$ & $118.8 \mathrm{a}$ & $2.9 \mathrm{a}$ & $2.3 \mathrm{a}$ & $5.6 \mathrm{a}$ & $5.1 \mathrm{a}$ & $10.7 \mathrm{a}$ & $9.8 \mathrm{a}$ \\
\hline Hybrids & Genotypes & & & & & & & & \\
\hline F1(Stevens x Flora Dade) & Normal & $98.3 \mathrm{~b}$ & $118.0 \mathrm{a}$ & $2.1 \mathrm{c}$ & $2.4 \mathrm{~b}$ & $4.0 \mathrm{~b}$ & $5.7 \mathrm{ab}$ & $8.8 \mathrm{ab}$ & $9.2 \mathrm{~b}$ \\
\hline F1(Stevens x TOM-559) & alc $+/$ alc & $106.3 \mathrm{a}$ & $119.3 \mathrm{a}$ & $3.5 \mathrm{a}$ & $4.5 \mathrm{a}$ & $6.3 \mathrm{a}$ & $6.6 \mathrm{a}$ & $11.8 \mathrm{a}$ & $13.3 \mathrm{a}$ \\
\hline F1(NC8276x Flora Dade) & Normal & $104.5 \mathrm{ab}$ & $119.3 \mathrm{a}$ & $1.7 \mathrm{c}$ & $1.8 \mathrm{~b}$ & $4.1 \mathrm{~b}$ & $4.7 \mathrm{ab}$ & $6.6 \mathrm{~b}$ & $8.0 \mathrm{~b}$ \\
\hline F1(NC8276 x TOM-559) & alc + alc & $106.4 \mathrm{a}$ & $123.5 \mathrm{a}$ & $3.2 \mathrm{ab}$ & $2.6 \mathrm{~b}$ & $5.5 \mathrm{ab}$ & $6.4 \mathrm{ab}$ & $11.2 \mathrm{a}$ & $13.5 \mathrm{a}$ \\
\hline $\begin{array}{l}\text { F1(Piedmont x Flora } \\
\text { Dade) }\end{array}$ & Normal & $97.8 \mathrm{~b}$ & $120.0 \mathrm{a}$ & $2.4 \mathrm{bc}$ & $1.7 \mathrm{~b}$ & $4.7 \mathrm{~b}$ & $3.8 \mathrm{~b}$ & $9.1 \mathrm{ab}$ & $8.6 \mathrm{~b}$ \\
\hline F1(Piedmont x TOM-559) & alc $c^{+} /$alc & $102.0 \mathrm{ab}$ & $117.5 \mathrm{a}$ & $3.4 \mathrm{a}$ & $2.9 \mathrm{ab}$ & $6.5 \mathrm{a}$ & $6.4 \mathrm{ab}$ & $12.4 \mathrm{a}$ & $11.0 \mathrm{ab}$ \\
\hline \multirow{2}{*}{\multicolumn{2}{|c|}{ Contrast of interest }} & \multicolumn{8}{|c|}{ Estimatives } \\
\hline & & & & & & & & & \\
\hline \multirow{2}{*}{\multicolumn{2}{|c|}{$\begin{array}{l}\text { alc } c^{+} / \text {alc } v s \text { alc } c^{+} / \text {alc }^{+} \text {in hybrids with } \\
\text { Stevens maternal line } \\
\text { alc } c^{+} / a l c \text { vs alc } / \text { alc } \\
\text { NC } 8276 \text { maternal line }\end{array}$}} & $8.0 *$ & $1.3^{\mathrm{ns}}$ & $1.4 *$ & $2.1 *$ & $2.3 * *$ & $0.9^{\mathrm{ns}}$ & $3.0^{\mathrm{ns}}$ & $4.1 *$ \\
\hline & & $1.9^{\mathrm{ns}}$ & $4.2^{\mathrm{ns}}$ & $1.5 * *$ & $0.8^{\mathrm{ns}}$ & $1.4^{\mathrm{ns}}$ & $1.7^{\mathrm{ns}}$ & $4.6^{*}$ & $5.5 * *$ \\
\hline \multicolumn{2}{|c|}{$\begin{array}{l}\text { alc } c^{+} / \text {alc } v s \text { alc } c^{+} / a l c^{+} \text {in hybrids with } \\
\text { Piedmont maternal line }\end{array}$} & $4.2^{\mathrm{ns}}$ & $-2.5^{\mathrm{ns}}$ & $1.0 *$ & $1.2^{\mathrm{ns}}$ & $1.8^{*}$ & $2.6^{*}$ & $3.3^{\mathrm{ns}}$ & $2.4^{\mathrm{ns}}$ \\
\hline
\end{tabular}

${ }^{11}$ Means followed by a common letter are not different by Duncan test $(\alpha=0.05)$.

$* *, *$ Significant at $1 \%$ and $5 \%$, respectively, by $\mathrm{F}$ test. 
effects of alcobaça in heterozygosity are independent from the utilized background, and followed the same tendencies regardless of fruit position in the plant. The genotypic background can be manipulated in addition to using the alc ripening mutant, to promote increased shelf life of fruits.

\section{REFERENCES}

ARAÚJO, M.L. de. Interações intra-loco e inter-locos alcobaça, crimson e high pigment sobre características de qualidade e de produção de frutos de tomateiro. Lavras: UFLA, 1997. 131p. (Tese - Doutorado)

CALBO, A.G.; NERY, A.A. Medida de firmeza em hortaliças pela técnica de aplanação. Horticultura Brasileira, v.13, p.14-18, maio 1995.

CERMENÕ, Z.S. Prontuário do horticultor. Lisboa: Litexa, 1988. 408p.

FARIA, M.V. Produtividade e qualidade pós-colheita de frutos de híbridos de tomateiro heterozigotos nos locos alcobaça (alc),crimson $\left(\mathrm{og}^{\mathrm{C}}\right)$ e/ou high pigment ( $h p$ ) Lavras: UFLA, 2000. 74p. (Dissertação - Mestrado)

FILGUEIRA, F.A.R. Novo manual de olericultura: agrotecnologia moderna na produção e comercialização de hortaliças. Viçosa: UFV, 2000. 402p.

FLORI, J.E. Obtenção e avaliação de híbridos $\mathrm{F}_{1}$ de tomate (Lycopersicon esculentum Mill.) no grupo multilocular. Lavras: Escola Superior de Agricultura de Lavras, 1993. 44p. (Dissertação Mestrado)

FLORI, J.E.; MALUF, W.R. Obtenção e avaliação de híbridos $\mathrm{F}_{1}$ de tomate (Lycopersicon esculentum Mill.) do grupo multilocular. Ciência e Prática, v.18, p.395-398, 1994.

FREITAS, J.A. Produtividade e qualidade de frutos de híbridos de tomateiros, heterozigoto na loco alcobaça. Lavras: UFLA, 1996. 87p. (Dissertação - Mestrado)

FREITAS, J.A. de; MALUF, W.R.; GOMES, L.A.A.; OLIVEIRA, A.C.B. de; MARTINS, W. da S.; BRAGA, R. de S. Padrão de amadurecimento e conservação pós-colheita de frutos de tomateiro, em função das diferentes constituições genotípicas no loco alcobaça. Revista Brasileira de Fisiologia Vegetal, v.10, p.191-196, 1998.
HOBSON, G.E. Effects of alleles at the never ripe locus on ripening of tomato fruit. Phytochemistry, v.6, p.1337-1341. 1967.

McGLASSON, W.B.; DOSTAL,H.C.; TIGCHELAAR, E.C. Comparison of propylene induced responses of immature fruit of normal and rin mutant tomatoes. Plant Physiology, v.55, p.218-222. 1975.

MUTSCHLER, M.A.; WOLFE, D.W.; COBB, E.D.; YOURSTONE, K.S. Tomato fruit quality and shelf life in hybrids heterozygous for the alc ripening mutant. HortScience, v.27, p.352-355, 1992.

NG,T.J.; TIGCHELAAR, E.C. Action of the non-ripening (nor) mutant on fruit ripening of tomato. Journal of the American Society for Horticultural Science, v.102, p.504-509. 1977.

RESENDE, J.M. Qualidade pós-colheita de dez genótipos de tomateiro do grupo multilocular. Lavras: UFLA, 1995. 88p. (Dissertação - Mestrado)

ROBINSON, R.W.; TOMES, M.L. Ripening inhibitor: a gene with multiple effects on ripening. Report of the Tomato Genetics Cooperative, v.18, p.36-37. 1968.

SAS INSTITUTE. SAS/STAT user's guide. Cary: SAS Institute, 1990.

SOUZA, J.C. de. Avaliação de tomateiros híbridos, do grupo multilocular, portadores do alelo alcobaça em heterozigose. Lavras: UFLA, 1995. 56p. (Dissertação - Mestrado)

VILAS BOAS, E.V.B. Maturação pós-colheita de híbridos de tomate heterozigotos no loco alcobaça. Lavras: UFLA, 1998. 105p. (Tese Doutorado)

TIGCHELAAR, E.C. Tomato ripening mutants. HortScience, v.13, p.502. 1978.

TIGCHELAAR, E.C.; TOMES, M.L.; BARMAN, R.J. A new fruit-ripening mutant, non-ripening (nor). Report of the Tomato Genetics Cooperative, v.23, p.33-34. 1973.

Received November 29, 2001 